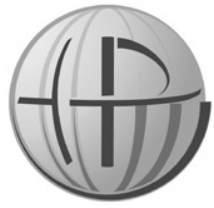

Horyzonty Polityki 2020, Vol. 11, No 34

\section{Mateusz Pękala}

http://orcid.org/0000-0002-1389-2664 Akademia Ignatianum w Krakowie Instytut Nauk o Polityce i Administracji e-mail: mateusz.pekala@ignatianum.edu.pl

DOI: $10.35765 /$ HP.1871

\title{
Globalizacja obojętności czy globalizacja solidarności?
}

\section{Streszczenie}

CEL NAUKOWY: Papież Franciszek jako jeden z liderów społeczności światowej często podejmuje temat globalizacji. Artykuł przedstawia poglądy papieża o negatywnie rozumianej "globalizacji obojętności” i pozytywnie rozumianej "globalizacji solidarności" w kontekście wyzwań stojących przed naukami o polityce i administracji.

PROBLEM I METODY B ADAWCZE: Analizie poddano orędzia papieża Franciszka z okazji Światowego Dnia Pokoju z lat 2014-2019 pod kątem najważniejszych wyzwań stojących aktualnie przed społecznością światową oraz kierunków jej dalszego rozwoju. Analiza ma charakter jakościowy i koncentruje się na rekonstrukcji i syntezie merytorycznych treści badanych komunikatów zarówno w warstwie deskryptywnej, jak i normatywnej.

PROCES WYWODU: Jednym z głównych zagrożeń jest współcześnie „globalizacja obojętności" rozumiana jako pogoń za zyskiem i zamknięcie się na potrzeby najsłabszych. Chrześcijańską odpowiedzią na nią powinna być "globalizacja solidarności", czyli odnowa ładu społecznego opartego na wartości ogólnoludzkiego braterstwa.

WYNIKI ANALIZY NAUKOWEJ: Papież zwraca uwagę na wiele negatywnych zjawisk powiązanych z globalizacja, jednocześnie traktując ten proces jako szansę na rozwiązanie wielu problemów społecznych. Papież daje konkretne wskazówki co do koniecznych działań. Generalny konsens społeczności międzynarodowej jednak nie wystarczy, konieczne są wielopoziomowe reformy w celu przełożenia uniwersalnych wartości ludzkich na konkretne działania w różnych częściach świata. 
WNIOSKI, INNOWACJE, REKOMENDACJE: W realizacji koncepcji globalizacji solidarności dużą rolę mogą odegrać nauki społeczne, których zadaniem jest m.in. opracowanie nowego modelu przywództwa politycznego, budowanego na ogólnoludzkich wartościach braterstwa i solidarności, odrzucającego metody walki i dominacji, a opartego na wzajemnym szacunku, zaufaniu i dialogu społecznym.

\section{SŁowA KLUCzowe:}

globalizacja, solidarność, braterstwo, przywództwo, papież Franciszek

\section{Abstract \\ GLOBALISATION OF INDIFFERENCE OR GLOBALISATION OF SOLIDARITY?}

RESEARCH OBJECTIVE: As one of the leaders of the world community, Pope Francis often takes up the subject of globalisation. The article presents the Pope's views on the negatively understood 'globalization of indifference' and the positively understood 'globalization of solidarity' in the context of the challenges facing the social sciences.

RESEARCH PROBLEM AND METHODS: The messages of Pope Francis on the occasion of World Day of Peace 2014-2019 were analyzed in terms of the most important challenges currently facing the world community and the directions of its further development. The analysis is of a qualitative nature and focuses on the reconstruction and synthesis of the substantive content of the messages studied, both in descriptive and normative terms.

THE PROCESS OF ARGUMENTATION: One of the main threats today is the 'globalization of indifference' understood as the pursuit of profit and closing in on the needs of the weakest. The Christian response to it should be the 'globalization of solidarity', i.e. the renewal of social order based on the value of human brotherhood.

RESEARCH RESULTS: The Pope draws attention to many negative phenomena associated with globalisation, while at the same time treating this process as an opportunity to solve many social problems. The Pope gives concrete guidance on the necessary actions. The general consensus of the international community, however, is not enough; multi-level reforms are needed to translate universal human values into concrete actions in different parts of the world.

CONCLUSIONS, INNOVATIONS AND RECCOMENDATIONS: Social sciences can play an important role in the realization of the concept of 
'globalization of solidarity', whose task is, among others, to develop a new model of political leadership, based on universal values of brotherhood and solidarity, rejecting methods of struggle and domination, and based on mutual respect, trust and social dialogue.

\section{KeYwORDS:}

globalization, solidarity, brotherhood, leadership, Pope Francis

\section{A. WSTĘP}

Globalizacja to jeden z najpopularniejszych tematów podejmowanych aktualnie przez badaczy społecznych. Za znanym brytyjskim socjologiem Anthonym Giddensem (Giddens, 2008; 2009), najczęściej określa się ten proces jako

intensyfikację relacji społecznych o zasięgu światowym, dzięki której oddalone od siebie miejsca staną się tak powiązane, że na wydarzenia w jednym miejscu wpływają inne wydarzenia, które rozgrywają się w miejscach oddalonych wiele kilometrów, i odwrotnie (Rothert, 2011, s. 71; podobnie Wnuk-Lipiński, 2004, s. 19).

Szczegółowych definicji globalizacji sformułowano bardzo wiele, a można je generalnie podzielić na trzy rodzaje: jednoaspektowe i abstrakcyjne; wartościująco-oceniające oraz wieloaspektowe (Wosińska, 2008, s. 23-26). Dla większości ujęć punktem wyjścia jest uznanie, że globalizacja oznacza strukturalną zmianę skali organizacji życia społecznego i gospodarczego człowieka, przejawiającą się m.in. tym, że za pomocą nowych technologii częściej podróżujemy, łatwiej komunikujemy się z osobami będącymi bardzo daleko, mamy lepszy dostęp do informacji, przez co nasz świat staje się „mały i płaski” (Rothert, 2011, s. 71). Nowego znaczenia nabierają relacje "pomiędzy «szczególnym» a «ogólnym», pomiędzy lokalnością a globalnościa, czy wreszcie pomiędzy partykularyzmem a uniwersalizmem" (Wnuk-Lipiński, 2004, s. 19). Jedno z wielu ujęć globalizacji traktuje ją zaś jako proces polegający na szybkiej relatywizacji oraz modernizacji życia społecznego, a więc powiązany z upadkiem tradycyjnych systemów wartości (Wnuk-Lipiński, 2004, s. 24-28; Waleszczuk, 2006, s. 122-125). 
Zacieśnianie wzajemnych powiązań w skali globu trwa od wieków, jednak aktualnie dynamika tego procesu niewątpliwie wzrasta (Wnuk-Lipiński, 2004, s. 15-18; Wosińska, 2008, s. 26-30). Jest to $\mathrm{w}$ istocie łańcuch zmian o charakterze wielokierunkowym, wpływający jednocześnie na wiele sfer życia. Mówi się o globalizacji w aspektach: językowo-kulturowym, ekonomiczno-handlowym, rynku pracy, demograficzno-społecznym, ekologicznym, technologicznym oraz politycznym (Waleszczuk, 2006, s. 35-68, Wosińska, 2008, Łużyński, 2013). W sferze publicznej

globalny obieg informacji wpływa na przyspieszenie procesów politycznych, a więc również na tworzenie się kaskady ogólnoświatowych konsekwencji (Rothert, 2011, s. 72).

Systemy społeczno-polityczne stają się coraz bardziej współzależne, jednocześnie wzrasta potęga instytucji międzynarodowych. Zmienia się także model sprawowania władzy politycznej, która teraz

należy do aktorów zbiorowych, a rządzenie polega na negocjacjach, współpracy, kompromisie i adaptacji. Zazwyczaj prowadzi to do wytwarzania się mniej sformalizowanych sposobów podejmowania decyzji (Rothert, 2011, s. 68).

Tradycyjny podział na rządzących i rządzonych jest coraz mniej widoczny:

Zmianie ulega koncepcja rządzenia, które przestaje polegać na wydawaniu poleceń, interweniowaniu czy regulowaniu. $W$ ich miejsce pojawia się zachęcanie, kooperacja, koordynacja i działanie systemowe w postaci zintegrowanego, holistycznego sposobu realizacji zadań (Wojniak, 2016, s. 78).

Mamy do czynienia z lawinowym wzrostem liczby i roli międzynarodowych organizacji rządowych i pozarządowych, ale władza w zglobalizowanym świecie jest rozłożona niesymetrycznie - najwięcej zyskują te podmioty, które mają najwięcej zasobów i potrafią sprawnie działać (Rothert, 2011, s. 80-81). Nowe uwarunkowania przywództwa w sferze publicznej wymagają nowego podejścia osób biorących odpowiedzialność za konkretne funkcje społeczne. 
W wielu środowiskach, od obywateli, przez publicystów, po grona eksperckie, toczy się dyskusja na temat pozytywnej lub negatywnej oceny globalizacji - całościowo lub w odniesieniu do jej wybranych aspektów. Formułowanych jest wiele stanowisk, wśród których znajdziemy zarówno radykalnych zwolenników, jak i zagorzałych krytyków. Podejście umiarkowane polega zaś na dostrzeżeniu potencjalnych (lub już dostrzeganych) zagrożeń przy próbie konstruktywnej refleksji nad sposobami przeciwdziałania im oraz nad drogami do wykorzystania nowych szans (Tarkowska, 2004, s. 204-209). Do tematów wzbudzających największe emocje należą: wzrost dysproporcji pomiędzy państwami bogatymi a biednymi i tzw. nowe ubóstwo, tolerowanie naruszeń praw człowieka, nierówny dostęp do wiedzy i do informacji, wzrost skali ruchów migracyjnych czy kryzys ekologiczny (Dylus, 2005, s. 35-44; Waleszczuk, 2006, s. 127-132; Mandle, 2009; Bocian, 2012). Przyczyny i skutki globalizacji stały się nie tylko polem dociekań naukowych, ale także nieodłączną i ważną częścią dyskursu społecznego i politycznego.

\section{B. PROBLEM BADAWCZY, METODOLOGIA}

\section{MATERIAŁ BADAWCZY}

Do autorytetów często podejmujących temat pozytywnych i negatywnych aspektów globalizacji należy papież Franciszek. Kardynał Jose Mario Bergoglio SJ objął urząd papieski 13 marca 2013 r. i od samego początku dawał wyraz nowemu stylowi, w jaki zamierza sprawować pontyfikat poprzez: reformy instytucjonalne, sposób podejmowania decyzji, specyficzny styl komunikacji, zmianę niektórych obyczajów i duże zaangażowanie w konkretne inicjatywy globalne i lokalne (metafora Kościoła jako społecznego „szpitala polowego"). W tym kontekście można sformułować następujące pytania badawcze: w jaki sposób papież opisuje sytuację współczesnych społeczeństw i jakie formułuje postulaty w tym zakresie? Jak ocenia globalizację? Czy w jego nauczaniu zawarta jest jakaś koncepcja społeczności globalnej, a jeśli tak, to na jakich założeniach jest ona oparta? Jako osoba sprawująca przywództwo instytucjonalne i religijne Biskup Rzymu wpływa na struktury Kościoła, organizacje religijne i społeczne oraz na postawy wiernych na całym świecie. 
Suweren Państwa Watykańskiego odgrywa też ważną rolę w stosunkach międzynarodowych, w sferze dyplomacji i polityki. Jest także autorytetem moralnym i jednym z głównych liderów międzynarodowej opinii publicznej, cieszącym się dużym zainteresowaniem mediów. Celem naszych rozważań jest próba udzielenia przynajmniej częściowej odpowiedzi na pytanie o poglądy papieża Franciszka na temat aktualnego stanu stosunków międzynarodowych. Na podstawie analizy treści wybranych orędzi Ojca Świętego przedstawimy jego poglądy na temat przyczyn i skutków "globalizacji obojętności", a także postulaty związane z pozytywną koncepcją "globalizacji solidarności".

Do realizacji powyższego celu wykorzystamy metodę jakościowej analizy treści, która może być stosowana do badania zarówno zawartości, jak i kontekstu różnego typu aktów komunikacji społecznej, przy użyciu wybranych kategorii znaczeniowych (Silverman, 2008, s. 148-150; Tabin, 2004, s. 15). Takie podejście umożliwia obiektywną rekonstrukcję założeń przyjętych przez autora danej wypowiedzi w odniesieniu do wybranych zagadnień, np. zjawisk i procesów społecznych. Brać pod uwagę można takie kryteria, jak np.: temat komunikatu, sposób sformułowania tematu, treści merytoryczne, przyjęte przez autora wartości i cele, sposoby ich realizacji, warstwa retoryczna i perswazyjna komunikatu oraz stosunek do adresatów (Frankfort-Nachmias, 2001, s. 345; Frieskie, 2018, s. 14). Dla badacza społecznego nauczanie papieskie, szczególnie $\mathrm{w}$ zakresie dotyczącym stanu stosunków społeczno-gospodarczych, rozwiązań prawno-ustrojowych oraz aktualnych problemów globalnych i lokalnych, może być traktowane jako część szeroko rozumianego dyskursu publicznego, którego analiza, nawet ograniczona do wybranych aspektów, często prowadzi do zwrócenia uwagi na nowe zagadnienia (Babbie, 2007, s. 107-108). Co więcej, akty komunikacji społecznej, szczególnie te skierowane do bardzo szerokiego grona odbiorców, mają przynajmniej do pewnego stopnia charakter konstytutywny, czyli w pewien sposób kreują społeczną rzeczywistość (Rittel, 2005, s. 11-12).

Na materiał badawczy poddany analizie składa się zbiór orędzi papieża Franciszka przygotowanych z okazji obchodów Światowego Dnia Pokoju w latach 2014-2019, według treści każdego dokumentu, który został opublikowany w oficjalnym serwisie internetowym 
Stolicy Apostolskiej ${ }^{1}$. Tradycję orędzi noworocznych zapoczątkował papież Paweł VI w 1968 r. Światowy Dzień Pokoju ma być świętem nie tylko katolików, dlatego komunikaty kierowane są „do wszystkich ludzi dobrej woli”. Na przykład list z roku 2015 został zaadresowany do „każdego mężczyzny i kobiety, jak również do wszystkich ludów i narodów świata, do szefów państw i rządów, do zwierzchników różnych religii" (Franciszek, 2015, pkt. 1, podobnie: 2016, pkt. 1 i 6), natomiast w liście z roku 2017 papież składa życzenia

mieszkańcom i narodom świata, szefom państw i rządów, a także zwierzchnikom wspólnot religijnych oraz różnych instytucji społeczeństwa obywatelskiego (2017, pkt. 1).

Treść komunikatów ma oficjalne tłumaczenia nie tylko na język angielski, ale też m.in. na arabski, chiński, francuski, hiszpański, niemiecki, portugalski czy rosyjski - zatem rzeczywiście są to apele skierowane do całego świata.

Orędzia papieża Franciszka, oprócz części teologicznej, zawierają rozważania filozoficzno-społeczne, dotyczące nie tylko spraw wiary, ale też kwestii ekonomicznych, politycznych, socjalnych, humanitarnych czy związanych ze stosunkami międzynarodowymi. Jeśli chodzi o styl komunikatów, to można przypuszczać, że papież wnosi osobiście duży wkład $\mathrm{w}$ ich treść merytoryczna, ponieważ są one pisane $\mathrm{w}$ konwencji podobnej do wygłaszanych przez niego przemówień, miejscami zawierają stwierdzenia bardzo emocjonalne, wiele $\mathrm{w}$ nich dosadnych sformułowań i konkretnych apeli. Papież jest $\mathrm{w}$ tym kontekście nie tylko $\mathrm{w}$ zwierzchnikiem religijnym czy dogmatycznym autorytetem moralnym, ale pokazuje, że jest także charyzmatycznym liderem i wrażliwym myślicielem społecznym, który skutecznie łączy rozważania teoretyczne z działaniami praktycznymi. Wiele mówią już same tytuły poszczególnych orędzi: „Braterstwo podstawą i drogą pokoju” (2014), ,Już nie niewolnicy, lecz bracia” (2015), „Przezwycięż obojętność i zyskaj pokój” (2016), „Wyrzeczenie się przemocy: styl polityki na rzecz pokoju” (2017), "Migranci i uchodźcy: mężczyźni i kobiety w poszukiwaniu pokoju” (2018), „Dobra polityka służy pokojowi” (2019). We wszystkich

1 http://www.vatican.va/content/francesco/pl/messages/peace.index.html (dostęp: 16.12.2019). 
komunikatach temat globalizacji jest obecny i stanowi albo główną oś narracji, albo szersze tło rozważań. Przedstawmy szczegółowe wyniki analizy.

\section{GLOBALIZACJA W ORĘDZIACH PAPIEŻA FRANCISZKA NA ŚWIATOWY DZIEŃ POKOJU Z LAT 2014-2019}

\section{Globalizacja obojętności}

Jeśli chodzi o kwestie definicyjne, to papież Franciszek postrzega globalizację zgodnie z najpopularniejszym ujęciem, a więc jako „zagęszczenie" relacji pomiędzy odległymi miejscami świata:

Nieustannie narastająca liczba wzajemnych powiązań i komunikacji, jakie spowijają naszą planetę, sprawia, że wśród narodów ziemi świadomość jedności i dzielenia wspólnego losu staje się bardziej namacalna. W ten sposób w dynamice historii, pomimo różnorodności grup etnicznych, kultur i społeczeństw, dostrzegamy zasiew powołania do tworzenia jednej wspólnoty, składającej się z braci, którzy nawzajem siebie przyjmuja, troszcząc się jedni o drugich (2014, pkt. 1).

Nauczanie papieża Franciszka o globalizacji jest kontynuacją refleksji podejmowanych przez jego poprzedników. Ojciec Święty nie ocenia jej całościowo, traktuje ją raczej jako okoliczność faktyczną. Globalizacja sama w sobie nie jest zatem dobra ani zła. Jest po prostu cechą naszej epoki i z jednej strony może się wiązać z różnymi zagrożeniami, z drugiej natomiast może być szansą na rozwiązanie wielu problemów. To jednak wymaga dużego wysiłku koniecznego przede wszystkim do urzeczywistnienia ideału ludzkiego braterstwa. Solidarność światowa nabiera szczególnego znaczenia, gdy trzeba rozwiązywać problemy, które przekraczają zakres kompetencji jednego państwa (2015, pkt. 6). Za Janem Pawłem II obecny papież określa postawę solidarności jako

mocną i trwałą wolę angażowania się na rzecz dobra wspólnego, czyli dobra wszystkich i każdego, wszyscy bowiem jesteśmy naprawdę odpowiedzialni za wszystkich (2016, pkt. 5, zob. także: 2014, pkt. 4). 
Powołując się zaś na swojego bezpośredniego poprzednika, papież Franciszek zwraca uwagę na najważniejsze wyzwanie współczesności:

Globalizacja, jak stwierdził Benedykt XVI, zbliża nas, ale nie czyni nas braćmi. Ponadto wiele sytuacji dysproporcji, biedy i niesprawiedliwości wskazuje nie tylko na głęboki brak braterstwa, ale także na brak kultury solidarności (2014, pkt. 1).

Natomiast z inspiracji nauczaniem Pawła VI płynie przypomnienie, że obowiązek braterstwa i solidarności

„dotyczy przede wszystkim najbardziej uprzywilejowanych", a chodzi m.in. o to, by kraje bogate pomagały mniej rozwiniętym, by kraje silniejsze przestrzegały zasad sprawiedliwości społecznej wobec krajów słabszych i aby postęp jednych państw nie przeszkadzał rozwojowi innych (2014, pkt. 4).

Wykorzystanie szansy, jaką daje globalizacja, jest wyzwaniem dla różnych sfer życia publicznego, w tym dla polityki, która może odegrać pozytywną albo negatywną rolę:

Polityka jest istotnym nośnikiem budowania obywatelstwa i dzieł człowieka, ale kiedy ci, którzy ją pełnia, nie przeżywają jej jako służby dla ludzkiej społeczności, może stać się narzędziem ucisku, marginalizacji, a nawet zniszczenia. (2019, pkt. 2).

Władza polityczna na poziomie krajowym i międzynarodowym powinna służyć przede wszystkim ochronie godności ludzkiej, poszanowaniu podstawowych praw i wolności ludzi, przeciwdziałaniu niesprawiedliwości, podziałom i zagrożeniom bezpieczeństwa. Papież wyraźnie wskazuje, że w dzisiejszym świecie „obojętność ma też wymiar instytucjonalny", a więc może być „,wpisana” w mechanizmy funkcjonowania instytucji publicznych i prywatnych (2016, pkt. 4). W myśl nauczania katolickiego każdy system społeczny i gospodarczy powinien być skoncentrowany przede wszystkim na osobie ludzkiej, a nie na pieniądzu (2015, pkt. 4). Współcześnie jednak to właśnie logika zysku za wszelką cenę ma decydujące znaczenie, co $\mathrm{w}$ połączeniu ze zubożeniem relacji międzyludzkich stało się jedną z przyczyn niedawnego światowego kryzysu finansowego (2014, pkt. 6). Sytuacji nie ułatwia także brak walki z korupcja, nazywaną 
przez Ojca Świętego „rakiem społecznym”, rozrastającym się na rządy, przedsiębiorców i instytucje społeczne (2019, pkt. 4, zob. także: 2014, pkt. 8, 2015, pkt. 4, 2016, pkt. 3).

Papież powstrzymuje się od całościowej oceny socjologicznie rozumianych procesów globalizacyjnych, jednak wiele uwagi poświęca temu, co nazywa "globalizacją obojętności". Jest to powszechna postawa zamknięcia się w sobie i niezauważania cierpienia innych osób (lub przyzwolenia na nie) (2014, pkt. 1, zob. także: 2015, pkt. 5). Obojętność jest często powiązana z zaniedbaniem etycznego obowiązku dbania o dobro wspólne, a zamykanie oczu na osoby cierpiące oznacza stawanie się współwinnym zła (2015, pkt. 6, 2016, pkt. 4). Papież stwierdza, że pokusa wygodnictwa jest obecna w ludzkiej naturze od zawsze, jednak aktualnie nabrała bardzo dużego, bo globalnego, zakresu (2016, pkt. 3). Kryzysowi braterstwa międzyludzkiego i solidarności społecznej sprzyjają: indywidualizm, egocentryzm, egoizm, materialistyczny konsumpcjonizm („,znieczulenie dobrobytem”), hedonizm, fałszywy humanizm, relatywizm, nihilizm, żądza zysku i pragnienie władzy, nieufność wobec obcych, postrzeganie innych ludzi jako narzędzi do wykorzystania, sprowadzanie stosunków międzyludzkich do transakcji handlowych, pogarda i odrzucenie słabszych jako bezużytecznych oraz odmawianie człowieczeństwa innym ludziom (2014, pkt. 1, 4, 8; 2015, pkt. 4; 2016, pkt. 3 i 4). Do negatywnych skutków globalizacji przyczyniają się te ideologie, które albo odrzucają wszelką transcendencję, albo nie uwzględniają wspólnego Ojca wszystkich ludzi, a przez to kwestionują powołanie do braterstwa z bliźnimi (2014, pkt. 1; 2016, pkt. 4). Braterstwo bowiem $\mathrm{w}$ perspektywie chrześcijańskiej to nie tylko uznanie tego co nas łączy z innymi, ale też przyjęcie różnic i podziałów, będących m.in. konsekwencją ludzkiej słabości i grzechu (2015, pkt. 2).

Na podstawie treści orędzi na Światowy Dzień Pokoju z lat 20142019 można zrekonstruować katalog najważniejszych bolączek współczesnego świata, przywoływanych nie po to, by nimi straszyć, ale po to, aby ukazać szanse na podjęcie skutecznej walki z tymi problemami. Do tematów będących przedmiotem troski Ojca Świętego należą:

- poważne naruszenia podstawowych praw człowieka w wielu częściach świata, m.in. prawa do życia i prawa do wolności religijnej, a także łamanie praw człowieka w czasie konfliktów społecznych (2014, pkt. 1 i 7); 
- wojny - zarówno w kontekście sił bezpośrednio biorących w nich udział, jak i w kontekście obojętności społeczności światowej (2014, pkt. 1 i 7); trwająca obecnie „trzecia wojna światowa w kawałkach" (2016, pkt. 2; 2017, pkt. 2);

- wojny ekonomiczne jako „wojny mniej widzialne, ale nie mniej okrutne, staczane na polu gospodarki i finansów, z użyciem środków równie niszczących życie, rodziny, przedsiębiorstwa" (2014, pkt. 1);

- ubóstwo - zarówno z punktu widzenia zinstytucjonalizowanych nierówności materialnych i bezrobocia, jak i w aspekcie „ubóstwa relacyjnego", czyli braku zaufania i osławienia więzi społecznych w rodzinach i wspólnotach (2014, pkt. 2 i 5; 2015, pkt. 2; 2016, pkt. 8);

- "plaga wyzysku” jednych ludzi przez drugich, szczególnie w miejscach pracy oraz przestępstwa finansowe i defraudacje (2014, pkt. 8; 2015, pkt. 1); dyskryminacja kobiet w różnych aspektach życia społecznego (2015, pkt. 5; 2016, pkt. 8);

- różne formy współczesnego niewolnictwa, które stanowi „zbrodnię obrazy człowieczeństwa”, a przejawia się „w różnych dziedzinach, formalnie i nieformalnie, od pracy domowej po rolnictwo, od przemysłu manufakturowego po górnictwo, zarówno w krajach, w których prawo pracy nie jest zgodne z minimalnymi normami i standardami międzynarodowymi, jak również, aczkolwiek wbrew prawu, w tych, w których ustawowo chroni pracowników" (2014, pkt. 8; 2015, pkt. 3);

- handel ludźmi, m.in. w celu eksplantacji organów, rekrutowania jako żołnierzy, żebraków, do pracy przy produkcji lub sprzedaży narkotyków, handel dziećmi w ramach nielegalnej adopcji międzynarodowej, porywanie kobiet $\mathrm{w}$ celu prostytucji lub zmuszenia do małżeństwa, porywanie ludzi przez terrorystów dla okupu (2014, pkt. 1 i 8; 2015, pkt. 3);

- trudna sytuacja wielu imigrantów i uchodźców, którzy są często pozbawiani wolności i dóbr, wykorzystywani fizycznie i seksualnie, przetrzymywani w nieludzkich warunkach, zmuszani do życia w sytuacji nielegalności albo dla legalności rezygnujący ze swojej godności (2014, pkt. 3 i 8; 2016, pkt. 8; 2018, pkt. 4);

- brak dostatecznej opieki nad wieloma osobami cierpiącymi z powodu chorób (2016, pkt. 8); 
- przemoc w rodzinach i krzywdzenie nieletnich (2014, pkt. 8; 2017, pkt. 5);

- utrzymująca się od wielu lat „hańba głodu na świecie” (2014, pkt. 8);

- nieludzkie warunki w wielu więzieniach (2014, pkt. 8; 2016, pkt. 8);

- dewastacja środowiska naturalnego i nieodpowiednie traktowanie zwierząt (2014, pkt. 8 i 9; 2016, pkt. 3 i 4).

Powyższe objawy globalizacji obojętności to swoista mapa problemów społecznych, które wymagają konkretnych działań "tu i teraz", ale są też przyczynkiem do bardziej ogólnej refleksji nad kierunkiem, w którym zmierza rozwój naszej cywilizacji. Do tego drugiego wątku powrócimy niżej, tymczasem zauważmy, że papież dostrzega i docenia duży dorobek oraz spore zaangażowanie wielu kościelnych i świeckich organizacji i osób niosących pomoc potrzebującym w różnych częściach świata (2014, pkt. 8; 2015, pkt. 5; 2016, pkt. 7). Ci aktorzy społeczni realizują w praktyce ideał globalizacji solidarności.

\section{Globalizacja solidarności}

Koncepcja globalizacji solidarności, będąca jednym z wątków przewodnich analizowanych orędzi, ma swoje korzenie w nauczaniu Jana Pawła II, była rozwijana także przez Benedykta XVI i może być traktowana jako konstruktywna odpowiedź katolików na współczesne wyzwania społeczne (Dylus, 2005, s. 129, 174-192; Waleszczuk, 2006, s. 245-328). Sama idea solidarności jest obecna w katolickiej nauce społecznej od dawna, pojawia się w wielu kontekstach i w wielu znaczeniach (Waleszczuk, 2006, s. 18-27, 157-244). Jednym z wątków $\mathrm{w}$ debacie na temat solidarności społecznej w warunkach globalizacji jest rola Kościoła, który może występować albo w roli wspólnoty osób wyznających te same wartości, albo w roli jednej z wielu grup interesów (zob. np. Dylus, 2005, s. 157-172). Nie ulega wątpliwości, że papież Franciszek stara się kontynuować i konkretyzować koncepcję globalizacji solidarności po to, aby zacieśnianie relacji w skali świata mogło przyczynić się do promowania i realizowania zasady międzyludzkiego braterstwa: 
Istnieje wiele powodów, aby wierzyć w zdolność ludzkości do wspólnego działania w solidarności, w uznaniu swego wzajemnego powiązania i współzależności, mając na uwadze członków najsłabszych oraz ochronę dobra wspólnego. (...) Jako stworzenia obdarzone niezbywalną godnością żyjemy w relacji z naszymi braćmi i siostrami, wobec których mamy odpowiedzialność i z którymi działamy solidarnie. Bez tej relacji bylibyśmy zubożeni w człowieczeństwie (Franciszek, 2016, pkt. 2).

Dużą rolę odgrywają tu postawy jednostek, ale Ojciec Święty stwierdza wprost, że dzisiejszy świat potrzebuje nowej całościowej wizji ładu społecznego, opartego przede wszystkim na odrzuceniu instrumentalnego wykorzystywania innych ludzi i promującego nie tylko ogólną otwartość na innych, ale realizującego w praktyce takie cnoty moralne, jak: roztropność, umiarkowanie, sprawiedliwość i męstwo (2014, pkt. 6). Wyzwanie to dotyczy zarówno instytucji publicznych, jak i prywatnych.

Papież wskazuje, że pierwszym krokiem do odnowy życia społecznego jest podjęcie zdecydowanej walki z wadami życia politycznego na trzech poziomach: osobistym, środowiskowym i instytucjonalnym (2019, pkt. 4). Nowi liderzy polityczni powinni dbać o interes wspólny i być dobrymi reprezentantami poszczególnych grup społecznych, a w swoich działaniach kierować się przede wszystkim kryteriami przejrzystości i poczuciem odpowiedzialności. Ważne jest, aby podejmowanie i realizowanie decyzji publicznych nie odbywały się w "klimacie nieustannego konfliktu”, a w atmosferze wzajemnego zaufania i przy szczerym zaangażowaniu wszystkich zainteresowanych (2014, pkt. 8; 2019, pkt. 5). Rozbieżności w opiniach i sprzeczne interesy nie powinny być podstawą budowania podziałów społecznych, podsycania antagonizmów lub wzajemnej obojętności, dlatego konieczne jest przyjęcie przez decydentów pozytywnej perspektywy w rozwiązywaniu problemów społecznych za pomocą dialogu (2017, pkt. 6). Na poziomie relacji osobistych, społecznych i międzynarodowych trzeba dbać o wyrzeczenie się przemocy oraz o odparcie pokusy zemsty, czego przykładem był upadek systemu komunistycznego w latach 90. XX w. (2017, pkt. 1 i 4).

Dobra polityka służy odpowiedniemu kształtowaniu życia społecznego w celu urzeczywistniania takich wartości, jak: sprawiedliwość, stabilność i trwały pokój (2014, pkt. 1). Jednak niestosowanie 
przemocy nie może być rozumiane jako kapitulacja wobec zła, ale raczej jako odpowiadanie na zło dobrem w celu przerwania spirali odwetu (2017, pkt. 3). Koncepcja globalizacji solidarności to pozytywna i konstruktywna odpowiedź na pytanie o kierunek, $w$ jakim powinien zmierzać rozwój społeczności globalnej. Tylko w ten sposób ludzkość będzie mogła podjąć skuteczną walkę ze wskazanymi wyżej ogólnymi przyczynami globalnej obojętności i z konkretnymi problemami społecznymi. Postawa otwartości i zaufania jest bardzo potrzebna w świecie, który zmienia się w bardzo szybkim tempie:

Braterstwo rodzi pokój społeczny, ponieważ tworzy równowagę między wolnością a sprawiedliwościa, pomiędzy odpowiedzialnością osobistą a solidarnością, między dobrem indywidualnym a dobrem wspólnym (2014, pkt. 8, zob. także: 2016, pkt. 2).

I w tym zakresie papież Franciszek kontynuuje myśl Jana Pawła II, który określał pożądany stan społecznego pokoju jako „dzieło solidarności" (2014, pkt. 4).

W analizowanych orędziach znajdziemy nie tylko ogólne, teologiczno-filozoficzne rozważania o konieczności moralnej odnowy ładu światowego, ale także wiele szczegółowych wskazówek na temat sposobów jej realizacji. Papież wyraźnie stwierdza, że nie chodzi o abstrakcyjne idee czy puste deklaracje na temat pomocy potrzebującym, ale o podjęcie wymiernego wysiłku w realizacji konkretnych, ale i trudnych inicjatyw (2018, pkt. 1). Ojciec Święty nie poprzestaje na ogólnym nakreśleniu "mapy globalnych problemów”, ale często proponuje istotne działania, które powinny być podjęte $\mathrm{w}$ określonych sytuacjach (np. 2014, pkt. 5, 7, 8; 2015, pkt. 5, 6; 2016, pkt. 7; 2017, pkt. 5; 2018, pkt. 4, 5). Wskazuje też tych aktorów życia publicznego, na których spoczywa odpowiedzialność za podjęcie słusznych decyzji, a są to m.in.: przywódcy międzynarodowi i państwowi, politycy, organizacje międzynarodowe i międzyrządowe, instytucje Kościoła katolickiego oraz przywódcy innych religii, przywódcy lokalni, administracja państwowa i służby, wojsko, organizacje pozarządowekościelne i świeckie, przedsiębiorcy, korporacje handlowe, media, dziennikarze, świat kultury, szkoły, wychowawcy i formatorzy, młodzież, rodziny oraz pojedynczy konsumenci (2014, pkt. 5, 7, 8, 9; 2015, pkt. 5; 2016, pkt. 2, 4, 7, 8; 2017, pkt. 5, 6; 2018, pkt. 1, 5). Podobne katalogi podmiotów społecznych zobowiązanych, zgodnie z zasadą 
pomocniczości, do włączenia się w łańcuch globalnej solidarności znajdziemy również w literaturze przedmiotu (zob. np. Dylus, 2005, s. 138-141). W rozwiązywaniu problemów globalnych liczy się każdy dobry gest (Franciszek 2015, pkt. 6; 2017, pkt. 5), jednak często nie wystarczą inicjatywy jednostkowe, a wymagana jest dobra organizacja i sprawna koordynacja działań na poziomie instytucji publicznych (Franciszek, 2015, pkt. 5).

Apel papieża Franciszka o przejście od globalizacji obojętności do globalizacji solidarności poparty jest nadzieją na to, że cała społeczność światowa uzna i przyjmie do realizacji zasadę braterstwa, którą wyznają zarówno chrześcijanie, jak i przedstawiciele innych religii i światopoglądów. Pozytywnym i uniwersalnym przekazem, który może połączyć wszystkich „ludzi dobrej woli”, jest chociażby ewangeliczny katalog Ośmiu Błogosławieństw (Franciszek, 2017, pkt. 6). W orędziu na rok 2019 papież zacytował zaś zbiór „Błogosławieństw polityka" opracowany przez wietnamskiego kardynała Francoisa Xaviera Nguyen Van Thuana (2019, pkt. 3):

Błogosławiony polityk, który dobrze rozumie swoją rolę w świecie. Błogosławiony polityk, którego postępowanie jest przykładem wiarygodności. Błogosławiony polityk, który pracuje dla wspólnego dobra, a nie dla własnego interesu. Błogosławiony polityk, który jest wierny sobie. Błogosławiony polityk, który trudzi się na rzecz budowania jedności. Błogosławiony polityk, który dąży do radykalnej zmiany. Błogosławiony polityk, który potrafi słuchać. Błogosławiony polityk, który się nie lęka.

\section{WNIOSKI}

Stolica Apostolska ma szczególny status w społeczności międzynarodowej i od lat wyróżnia się podejmowaniem różnych działań na rzecz pokoju na świecie (Gizicki, 2011). Natomiast orędzia noworoczne są dobrą ilustracją poglądów, jakie w zakresie aktualnych wyzwań społecznych papież Franciszek wyraża przy wielu okazjach - w oficjalnych dokumentach, przemówieniach czy wywiadach (zob. np. Franciszek, 2013a, 2013b, 2018). Analiza treści komunikatów prowadzi do wniosku, że globalizacja jest jednym z głównych wątków nauczania Ojca Świętego i że przywiązuje on do tego tematu dużą 
uwagę. Papież dostrzega, że dzisiejsze społeczeństwa doświadczają wieloaspektowych i dynamicznych zmian związanych nie tylko z postępem technologicznym i mobilnościa, ale też z nowymi zasadami budowania relacji na poziomie mikro-i makrospołecznym. Traktując globalizację jako jedno z uwarunkowań naszej epoki, papież stara się w sposób obiektywny dostrzec zarówno zagrożenia, jak i szanse z nią powiązane. Niestety, zacieśnianie więzi w skali globalnej przyczynia się często do pogłębiania podziałów społecznych, kryzysu zaufania i powszechnej obojętności. Ojciec Święty jest świadomy problemów społecznych występujących w różnych częściach świata i stara się o nich głośno mówić, aby uwrażliwiać sumienia decydentów oraz wszystkich osób, które mogą pomóc chociażby przez jeden drobny (materialny lub niematerialny) gest braterstwa. Jednocześnie dostrzega i docenia wiele dzieł, które aktualnie służą realizacji ideału globalizacji solidarności.

W jednej z publikacji na temat współczesnych systemów politycznych czytamy:

Krótko mówiąc, wchodzimy w epokę rewolucji. Wchodzimy w nią z ideami, przywódcami i instytucjami przystosowanymi do czasów, które minęły wieki temu (Rothert, 2011, s. 84).

Papież także za jedną z przyczyn globalizacji obojętności uznaje kryzys przywództwa politycznego, którego oznaką jest to, że sam termin „polityka” nabiera często negatywnego wydźwięku. Odnowa życia publicznego jest wyzwaniem wymagającym m.in. wypracowania nowego, pozytywnego stylu liderowania, które nie będzie oparte na strachu i bezradności, ale na proaktywnym poszukiwaniu trafnych diagnoz i najskuteczniejszych metod rozwiązywania problemów społecznych. W tym zakresie rozważania papieża Franciszka na temat globalizacji solidarności powinny stać się inspiracją dla tych przedstawicieli nauk społecznych, którzy podejmują deskryptywne i normatywne badania nad funkcjonowaniem sfery publicznej. Warto dostrzec, że dorobek takich dyscyplin, jak np. nauki o polityce i administracji, socjologia organizacji i zarządzania czy socjologia religii może (i powinien) służyć jako naukowa podstawa nowego modelu przywództwa publicznego. Dobrym przykładem może być to, że na podstawie wieloletnich badań dotyczących osiaggania optymalnych 
wyników w kierowaniu ludźmi powstała koncepcja Pięciu Naczelnych Zasad Wzorcowego Przywództwa, które brzmią następująco: wskazuj właściwą drogę; rozbudzaj wspólną wizję; nie bój się zmian; pozwól działać innym; motywuj i wspieraj (Kouzes, 2010, s. 13-20). Pozytywnie rozumiane przywództwo jest sztuką budowania uczciwych i trwałych relacji społecznych:

Związek oparty na strachu i nieufności nigdy nie przyniesie trwałych korzyści i wartości. Jedynie relacja oparta na wzajemnym zaufaniu i szacunku jest gwarancją wspólnego sukcesu, pomaga stawić czoła największym przeciwnościom i staje się inspiracją dla innych. (Kouzes, 2010, s. 21).

Natomiast fundamentem dla każdego rodzaju przywództwa jest wiarygodność (Kouzes, 2010, s. 32-36). O przejrzystość i rozliczalność w sferze polityki apeluje również papież.

Badacze społeczni podejmują próby określenia koniecznego „minimum etycznego" dla nowego modelu przywództwa publicznego (np. Michalski, 2011, s. 63-64), i również w tym zakresie Ojciec Święty daje konkretne i aktualne wskazówki. Kolejną istotną kwestią jest odpowiedź na pytanie, czy współczesny świat byłby w stanie przyjąć jednolity i spójny katalog zasad globalnej etyki obywatelskiej (Global Civic Ethics), a jeśli tak, to jakie wartości można do niego włączyć (Wojniak, 2016, s. 82-83). W tym kontekście papież stwierdza, że nawet osoby, które nie podzielają poglądu na istnienie uniwersalnej aksjologii ogólnoludzkiej, powinny kierować się sumieniem i są wezwane do walki z konkretnymi problemami społecznymi. Być może zarysowana wyżej mapa negatywnych zjawisk obecnych w zglobalizowanym świecie miałaby szansę być zaakceptowana przez globalną społeczność. Papież jest jednak realistą i zdaje sobie sprawę z tego, że ogólny konsens społeczności międzynarodowej to dopiero pierwszy krok do zmierzenia się z wyzwaniami współczesności i podjęcia współczesnych wyzwań, zaś porozumienia, strategie i reformy prawne są jak najbardziej dobre i potrzebne, ale na pewno nie wystarczą (Franciszek, 2015, ak. 3). Stąd też wynikają jego apele o konkretne i przemyślane działania na rzecz odnowy fundamentów ładu społecznego w epoce globalnej. 


\section{BibLIOGRAFIA}

Babbie, E., (2008). Podstawy badań społecznych, tłum. Witold Betkiewicz, Marta Bucholc, Przemysław Gadomski, Jacek Haman, Agnieszka Jasiewicz-Betkiewicz, Agnieszka Kloskowska-Dudzińska, Michał Kowalski, Maja Mozga-Górecka. Warszawa: Wydawnictwo Naukowe PWN.

Bocian, A.F. (2012). Globalizacja - kontekst etyczny. W: A.F. Bocian (red.), Globalizacja - polityka - etyka, t. I. Białystok: Wydawnictwo Uniwersytetu w Białymstoku, s. 236-254.

Chodubski, A. (2005). Cywilizacyjne formy przywództwa. W: L. Rubisz, K. Zuba (red.), Przywództwo polityczne. Teorie i rzeczywistość. Toruń: Wydawnictwo Adam Marszałek, s. 81-97.

Durska, A. (2011). O potrzebie badań nad przywództwem we współczesnej polityce. W: W. Konarski, A. Durska, S. Bachrynowski (red.), Kryzys przywództwa we wspótczesnej polityce, Warszawa: Wyd. SWPS "Academica", s. 11-15.

Dylus, A. (2005). Globalizacja. Refleksje etyczne, Wrocław: Wydawnictwo Ossolineum.

Frankfort-Nachmias, Ch., Nachmias, D. (2001). Metody badawcze w naukach społecznych, tłum. E. Hornowska, Poznań: Wydawnictwo Zysk i S-ka.

Frieske, K.W. (2018). Polityki publiczne: iluzje uniwersalnej racjonalności. W: J. Kwaśniewski (red.), Nauki o polityce publicznej. Monografia dyscypliny, Warszawa: Instytut Profilaktyki Społecznej i Resocjalizacji UW, s. 7-22.

Giddens, A. (2008). Konsekwencje nowoczesności, tłum. E. Klekot. Kraków: Wydawnictwo Uniwersytetu Jagiellońskiego.

Giddens, A. (2009). Europa w epoce globalnej, tłum. M. Klimowicz, M. Habura, red. nauk. wyd. pol. T. Żyro. Warszawa: Wydawnictwo Naukowe PWN.

Gizicki, W. (2011). Stolica Apostolska w środowisku międzynarodowym. Przesłanie na rzecz pokoju i bezpieczeństwa. W: W. Gizicki (red.), Polityczne wyzwania wspótczesnych państw. Perspektywa państw narodowych i Unii Europejskiej, t. II. Toruń: Wydawnictwo Adam Marszałek, s. $164-177$.

Franciszek (Papież) (2013a). Nie zgadzaj się na zło!, tłum. X. Bordas, H. Prószyńska-Bordas, K. Gołębiowski, o. S. Tasiemski OP, K. Tomasik, P. Bieliński. Kraków: Wydawnictwo M.

Franciszek (Papież) (2013b). Prawdziwa władza jest stużba, tłum. A. Fijałkowska-Żydok. Kraków: Esprit. 
Franciszek (Papież), Wolton, D. (2018). Otwieranie drzwi. Rozmowy o Kościele i świecie. Kraków: Wydawnictwo WAM.

Kouzes, J.M., Posner, B.Z. (2010). Przywództwo i jego wyzwania, tłum. A.E. Chudzio. Kraków: Wydawnictwo Uniwersytetu Jagiellońskiego. Łoś-Nowak, T. (2005). Przywództwo w świecie globalnym. W: L. Rubisz, K. Zuba (red.), Przywództwo polityczne. Teorie i rzeczywistość. Torun: Wydawnictwo Adam Marszałek, s. 207-230.

Łużyński, W. (2013). Globalna kwestia społeczna. Wybrane zagadnienia z perspektywy nauczania społecznego Kościoła. Torun: Wydawnictwo Naukowe Uniwersytetu Mikołaja Kopernika.

Mandle, J. (2009). Globalna sprawiedliwość, tłum. M. Dera. Warszawa: Wydawnictwo Sic!.

Michalski, B. (2011). Przywództwo: dialog pragmatyka z wartościami albo globalne przywództwo na rzecz zrównoważonego rozwoju, W: W. Konarski, A. Durska, S. Bachrynowski (red.), Kryzys przywództwa we wspótczesnej polityce. Warszawa: Wyd. SWPS „Academica”, s. 60-67.

Obacz, P. (2011). Systemowe źródła kryzysu przywództwa politycznego. W: W. Konarski, A. Durska, S. Bachrynowski (red.), Kryzys przywództwa we wspótczesnej polityce. Warszawa: Wyd. SWPS „Academica”, s. $133-142$.

Pałecki, K. (2005). Przywództwo jako kategoria teoretyczna i przedmiot społecznych oczekiwań. W: L. Rubisz, K. Zuba (red.), Przywództwo polityczne. Teorie i rzeczywistość. Toruń: Wydawnictwo Adam Marszałek, s. 32-37.

Pałecki, K. (2011). Wokół przywództwa politycznego - ramy dyskursu. W: A. Kasińska-Metryka (red.), Studia nad przywództwem politycznym. Ustalenia metodologiczne i praktyka. Toruń: Wydawnictwo Adam Marszałek, s. 9-20.

Rittel, S.J. (2005). Dyskurs w filozofii politycznej. Podejście lingwistyczno-politologiczne i systemowe. Kielce: Wydawnictwo Akademii Świętokrzyskiej im. Jana Kochanowskiego.

Rothert, A. (2011). Władza i sieci, czyli globalne przywództwo na rzecz zrównoważonego rozwoju. W: W. Konarski, A. Durska, S. Bachrynowski (red.), Kryzys przywództwa we współczesnej polityce. Warszawa: Wyd. SWPS „Academica”, s. 68-87.

Silverman, D. (2008). Interpretacja danych jakościowych. Metody analizy rozmowy, tekstu i interakcji, tłum. M. Głowacka-Grajper, J. Ostrowska. Warszawa: Wydawnictwo Naukowe PWN.

Tabin, M. (red.) (2004). Słownik socjologii i nauk społecznych. Warszawa: Wydawnictwo Naukowe PWN. 
Tarkowska, E. (2004). Globalizacja i ubóstwo. W: S. Amsterdamski (red.), Globalizacja i co dalej?. Warszawa: Wyd. IFiS PAN, s. 201-216.

Waleszczuk. Z. (2006). Globalizacja solidarności. Solidarność odpowiedzia na wyzwania procesów globalizacji w świetle nauczania społecznego Jana Pawła II. Wrocław: Papieski Wydział Teologiczny we Wrocławiu.

Wiemeyer, J. (2010). Sprawiedliwie ukształtowana globalizacja. W: S. Fel, M. Hułas, S.G. Raabe (red.), Społeczeństwo, gospodarka, ekologia. Perspektywa encykliki społecznej "Caritas in veritate". Lublin: Wydawnictwo KUL, s. 55-72.

Wnuk-Lipiński, E. (2004). Oblicza globalizacji - konceptualizacja pojęcia. W: S. Amsterdamski (red.), Globalizacja i co dalej?. Warszawa: Wyd. IFiS PAN, s. 15-309.

Wojniak, J. (2016). Obywatel w społeczeństwie sieci. Warunki i narzędzia spotecznej partycypacji w ponowoczesnym świecie. Kraków: Wydawnictwo Naukowe Uniwersytetu Pedagogicznego.

Wosińska, W. (2008). Oblicza globalizacji. Sopot: Smak Słowa.

Zuba, K. (2005). Przywództwo w teorii nauk politycznych. W: L. Rubisz, K. Zuba (red.), Przywództwo polityczne. Teorie i rzeczywistość. Toruń: Wydawnictwo Adam Marszałek, s. 11-31.

\section{Copyright and License}

This article is published under the terms of the Creative Commons Attribution - NoDerivs (CC BY- ND 4.0) License http://creativecommons.org/licenses/by-nd/4.0/ 